\title{
Umami Receptor Activation Increases Duodenal Bicarbonate Secretion via Glucagon-Like Peptide-2 Release in Rats
}

\author{
Joon-Ho Wang, Takuya Inoue, Masaaki Higashiyama, Paul H. Guth, Eli Engel, \\ Jonathan D. Kaunitz, and Yasutada Akiba
}

Department of Medicine, School of Medicine (J.-H.W, T.I., M.H., J.D.K., Y.A.) and Department of Biomathematics (E.E.), University of California, Los Angeles, California; Greater Los Angeles Veterans Affairs Healthcare System, Los Angeles, California (P.H.G., J.D.K., Y.A.); and Brentwood Biomedical Research Institute, Los Angeles, California (J.D.K., Y.A.)

Received June 6, 2011; accepted August 15, 2011

\begin{abstract}
Luminal nutrient chemosensing during meal ingestion is mediated by intestinal endocrine cells, which regulate secretion and motility via the release of gut hormones. We have reported that luminal coperfusion of L-Glu and IMP, common condiments providing the umami or proteinaceous taste, synergistically increases duodenal bicarbonate secretion (DBS) possibly via taste receptor heterodimers, taste receptor type 1, member 1 (T1R1)/R3. We hypothesized that glucose-dependent insulinotropic peptide (GIP) or glucagon-like peptide (GLP) is released by duodenal perfusion with L-Glu/IMP. We measured DBS with $\mathrm{pH}$ and $\mathrm{CO}_{2}$ electrodes through a perfused rat duodenal loop in vivo. GIP, exendin (Ex)-4 (GLP-1 receptor agonist), or GLP-2 was intravenously infused $(0.01-1 \mathrm{nmol} / \mathrm{kg} / \mathrm{h})$. L-Glu $(10 \mathrm{mM})$ and IMP $(0.1 \mathrm{mM})$ were luminally perfused with or without bolus intravenous injection ( 3 or $30 \mathrm{nmol} / \mathrm{kg}$ ) of the receptor antagonists Pro ${ }^{3}$ GIP, Ex-3(9-39), or GLP-2(3-33). GIP or GLP-2 infu-
\end{abstract}

sion dose-dependently increased DBS, whereas Ex-4 infusion gradually decreased DBS. Luminal perfusion of L-Glu/IMP increased DBS, with no effect of Pro $^{3}$ GIP or Ex-3(9-39), whereas GLP-2(3-33) inhibited L-Glu/IMP-induced DBS. Vasoactive intestinal peptide $(\mathrm{VIP})(6-28)$ intravenously or $N^{G}$-nitro-L-arginine methyl ester coperfusion inhibited the effect of L-Glu/IMP. Perfusion of L-Glu/IMP increased portal venous concentrations of GLP-2, followed by a delayed increase of GLP-1, with no effect on GIP release. GLP-1/2 and T1R1/R3 were expressed in duodenal endocrine-like cells. These results suggest that luminal L-Glu/IMPinduced DBS is mediated via GLP-2 release and receptor activation followed by VIP and nitric oxide release. Because GLP-1 is insulinotropic and GLP-2 is intestinotrophic, umami receptor activation may have additional benefits in glucose metabolism and duodenal mucosal protection and regeneration.

\section{Introduction}

The process of digestion is orchestrated in part by the coordinated release of gut hormones in response to meal ingestion. Although gut hormones are expressed primarily in the endocrine cells interspersed in the gut epithelium (enteroendocrine cells), the mechanism by which meal-related luminal molecules elicit hormone release has not been read-

This work was supported by a research grant from Ajinomoto, Inc. (Tokyo, Japan) (to Y.A.); a Department of Veterans Affairs Merit Review Award (to J.D.K.); the National Institutes of Health National Institute of Diabetes and Digestive and Kidney Diseases [Grant R01-DK54221] (to J.D.K.); and the Animal Core of the National Institutes of Health National Institute of Diabetes and Digestive and Kidney Diseases [Grant P30-DK0413] (to J. E. Rozengurt).

Article, publication date, and citation information can be found at http://jpet.aspetjournals.org.

doi:10.1124/jpet.111.184788 ily apparent. We have previously reported that the postprandial increase of protective duodenal epithelial $\mathrm{HCO}_{3}{ }^{-}$secretion is elicited by an increase in luminal $\mathrm{H}^{+}$and $\mathrm{PCO}_{2}$, which can activate submucosal $\mathrm{H}^{+}$chemosensors in addition to evoking luminal ATP release (Akiba and Kaunitz, 2011). Although gastric postprandial $\mathrm{H}^{+}$secretion is a logical trigger for eliciting duodenal $\mathrm{HCO}_{3}{ }^{-}$secretion, luminal nutrients are also present in high concentrations after a meal, which might serve as alternative activators of $\mathrm{HCO}_{3}{ }^{-}$secretion.

The availability of nearly pure populations of enteroendocrine cells has facilitated the identification of numerous nutrient-sensing G protein-coupled receptors expressed on endocrine cells, suggesting a plausible mechanism for the transduction of the luminal nutrient signal into hormone release across the enteroendocrine cell basolateral membrane (Engelstoft et al., 2008; Reimann et al., 2008). Thus,

ABBREVIATIONS: DBS, duodenal bicarbonate secretion; Ex, exendin; GIP, glucose-dependent insulinotropic peptide; GIP-R, GIP receptor; GLP, glucagon-like peptide; GLP-1R, GLP-1 receptor; GLP-2R, GLP-2 receptor; L-NAME, $N^{G}$-nitro-L-arginine methyl ester; NO, nitric oxide; NVP DPP 728, 6-[[2-[[2-(2S)-2-cyano-1-pyrrolidinyl]-2-oxoethyl]amino]ethyl]amino-3-pyridinecarbononitrile; PV, portal vein; T1R, taste receptor type 1; VIP, vasoactive intestinal peptide; VIP-R, VIP receptor; BSA, bovine serum albumin; COX, cyclooxygenase; EIA, enzyme immunoassay; PG, prostaglandin. 
one possible mechanism for eliciting duodenal mucosal $\mathrm{HCO}_{3}{ }^{-}$secretion is by the activation of nutrient sensors expressed on the enteroendocrine cell apical membrane, evoking hormone release into the submucosal space, which then stimulates $\mathrm{HCO}_{3}{ }^{-}$secretion from nearby epithelial cells. In support of this mechanism is our report that coperfusion of the duodenum of anesthetized rats with L-Glu and IMP stimulates $\mathrm{HCO}_{3}{ }^{-}$secretion, which is typical for activation of the T1R1/T1R3 umami taste receptor (Zhang et al., 2008; Akiba et al., 2009). Because this taste receptor is expressed on enteroendocrine cells (Jang et al., 2007; Mace et al., 2007), this mucosal response to luminal nutrients suggested a hormonally mediated mechanism for eliciting $\mathrm{HCO}_{3}{ }^{-}$secretion and enhancing other mucosal defense mechanisms.

Of the numerous hormones released in response to luminal amino acids, the proglucagon-derived hormones glucagonlike peptide (GLP)-1 and GLP-2 secreted from enteroendocrine L cells are appealing as mediators of L-Glu/IMP-evoked $\mathrm{HCO}_{3}{ }^{-}$secretion: GLP-1 is released by oral glutamine in humans (Greenfield et al., 2009), whereas GLP-2 modulates neurally evoked anion secretion in the guinea pig intestine (Baldassano et al., 2009). A third possible hormone mediator is gastric inhibitory peptide/glucose-dependent insulinotropic peptide (GIP), released from $\mathrm{K}$ cells, which is released by luminal amino acids (O'Dorisio et al., 1976) and enhances duodenal $\mathrm{HCO}_{3}{ }^{-}$secretion (Flemström et al., 1982; Konturek et al., 1985).

A possible secondary mechanism whereby GLP-2 increases the rate of $\mathrm{HCO}_{3}{ }^{-}$secretion is through the release of vasoactive intestinal peptide (VIP) from submucosal enteric nerves. Compelling data supporting this supposition include the well established secretagogue activity of VIP for duodenal epithelial $\mathrm{HCO}_{3}{ }^{-}$secretion (Isenberg et al., 1984), coexpression of VIP and GLP-2 receptor (GLP-2R) on enteric nerves (Guan et al., 2006), and mediation of the enteric smooth muscle and vasodilatory effects of GLP-2 by VIP and nitric oxide (NO) (Guan et al., 2006; Amato et al., 2009).

We thus tested the hypothesis that activation of umami taste receptors, expressed on enteroendocrine cells, evokes GLP-1, GLP-2, or GIP release, which then releases VIP from enteric nerves, eliciting epithelial $\mathrm{HCO}_{3}{ }^{-}$secretion. Here, we show that the umami ligands L-Glu + IMP evoked GLP-2 release, presumably from $\mathrm{L}$ cells, which activated GLP-2R, increasing the rate of $\mathrm{HCO}_{3}{ }^{-}$secretion, mediated by VIP and NO. Luminal L-Glu/IMP also increased GLP-1 release into portal vein (PV). Because GLP-1 is insulinotropic and GLP-2 is intestinotrophic, umami receptor activation by luminal amino acids may, in addition to evoking $\mathrm{HCO}_{3}{ }^{-}$secretion, protect and repair the duodenal mucosa while improving glycemic control.

\section{Materials and Methods}

Chemicals and Animals. GIP(1-39), exendin (Ex)-4, rat GLP-2, Ex-3(9-33), VIP(6-28), and 6-[[2-[[2-(2S)-2-cyano-1-pyrrolidinyl]-2oxoethyl]amino] ethyl]amino-3-pyridinecarbononitrile (NVP DPP 728) dihydrochloride were obtained from Tocris Bioscience (Ellisville, MO). Pro ${ }^{3}$ GIP was from Phoenix Pharmaceuticals (Belmont, CA). GLP-2(3-33) was synthesized by California Peptide Research, Inc. (Napa, CA). L-Glu, IMP, $N^{\mathrm{G}}$-nitro-L-arginine methyl ester (LNAME), L-Arg, indomethacin, capsaicin, atropine, bovine serum albumin (BSA), HEPES, and other chemicals were obtained from
Sigma (St. Louis, MO). Krebs' solution contained $136 \mathrm{mM} \mathrm{NaCl}, 2.6$ $\mathrm{mM} \mathrm{KCl}, 1.8 \mathrm{mM} \mathrm{CaCl}_{2}$, and $10 \mathrm{mM}$ HEPES at pH 7.0. Osmolarity was adjusted to isotonic by reducing $\mathrm{NaCl}$ concentration. The $\mathrm{pH}$ of the Krebs' solution was adjusted to $\mathrm{pH} 7.0$ after compounds were dissolved. All solutions were prewarmed to $37^{\circ} \mathrm{C}$ in a water bath; temperature was maintained using a circulating water heating pad. All studies were performed with approval of the Veterans Affairs Institutional Animal Care and Use Committee. Male Sprague-Dawley rats weighing 200 to $250 \mathrm{~g}$ (Harlan, Indianapolis, IN) were fasted overnight, but had free access to water.

Measurement of Duodenal $\mathrm{HCO}_{3}{ }^{-}$Secretion. Duodenal loops were prepared and perfused as described previously (Mizumori et al., 2006; Akiba et al., 2007, 2009). In brief, under isoflurane anesthesia (2\%), the proximal duodenal loop (perfused length $2 \mathrm{~cm}$ ) was perfused with $\mathrm{pH} 7.0$ normal saline by using a peristaltic pump (Thermo Fisher Scientific, Waltham, MA) at $1 \mathrm{ml} / \mathrm{min}$. The perfusate was bubbled with $100 \% \mathrm{O}_{2}$ and stirred and warmed at $37^{\circ} \mathrm{C}$ with a heating stirrer (Barnstead International, Dubuque, IA). The $\mathrm{pH}$ of the perfusate was kept constant at 7.0 with a pH stat (models PHM290 and ABU901; Radiometer Analytical, Lyon, France). Furthermore, to eliminate the buffer action of agonists or antagonists, which would overestimate or underestimate the titration volume using a $\mathrm{pH}$ stat, two sets of flow-through $\mathrm{pH}$ and $\mathrm{CO}_{2}$ electrodes (Lazar Research Laboratories, Inc., Los Angeles, CA) were connected in the perfusion loop where $\mathrm{pH}$ and $\mathrm{CO}_{2}$ concentration $\left(\left[\mathrm{CO}_{2}\right]\right)$ were simultaneously and continuously measured. Because the input (perfusate) $\left[\mathrm{CO}_{2}\right]$ is $\sim 0$, the effluent $\left[\mathrm{CO}_{2}\right]$ and $\mathrm{pH}$ were used to calculate the total $\mathrm{CO}_{2}$ output equivalent to the secreted $\mathrm{HCO}_{3}{ }^{-}$as described previously (Mizumori et al., 2006; Akiba et al., 2007). To prevent contamination of the perfusate from bile or pancreatic juice, the pancreaticobiliary duct was ligated just proximal to its insertion into the duodenal wall and cannulated with a PE-10 tube to drain the juice. After stabilization with continuous perfusion of $\mathrm{pH} 7.0$ saline for $\sim 30 \mathrm{~min}$, the time was set as $t=0$. The duodenal loop was perfused with $\mathrm{pH} 7.0$ saline from $t=0 \mathrm{~min}$ until $t=10 \mathrm{~min}$ (basal period). The perfusate was then changed to $\mathrm{pH} 7.0$ saline or $\mathrm{pH} 7.0$ Krebs buffer from $t=10 \mathrm{~min}$ until $t=35 \mathrm{~min}$ (challenge period), with or without chemicals. At $t=10 \mathrm{~min}$, the system was gently flushed so as to rapidly change the composition of the perfusate. Duodenal $\mathrm{HCO}_{3}{ }^{-}$secretion was expressed as total $\mathrm{CO}_{2}$ output calculated from the measured $\mathrm{pH}$ and $\left[\mathrm{CO}_{2}\right]$ in the effluent solution as reported previously (Akiba et al., 2007, 2009).

Experimental Protocol. To examine the effect of exogenous GIP, GLP-1, or GLP-2 on duodenal $\mathrm{HCO}_{3}{ }^{-}$secretion, vehicle $(0.1 \%$ BSA in sterile saline), a potent GIP receptor (GIP-R) agonist GIP(139), a high-affinity GLP-1 receptor (GLP-1R) agonist Ex-4 (Göke et al., 1993), or rat GLP-2 was intravenously infused $(0.01-1 \mathrm{nmol} / \mathrm{kg} / \mathrm{h})$ via femoral vein during the challenge period $(t=10-35 \mathrm{~min})$.

We have reported that luminal perfusion of L-Glu or IMP alone has little effect on duodenal $\mathrm{HCO}_{3}{ }^{-}$secretion, whereas coperfusion of L-Glu and IMP synergistically increases $\mathrm{HCO}_{3}{ }^{-}$secretion (Akiba et al., 2009). To investigate the involvement of GIP or GLP receptor in L-Glu/IMP-induced $\mathrm{HCO}_{3}{ }^{-}$secretion, vehicle $(0.1 \% \mathrm{BSA}$ in sterile saline), a specific GIP-R antagonist Pro ${ }^{3}$ GIP (Gault et al., 2005), a potent and selective GLP-1R antagonist Ex-3(9-39) (Göke et al., 1993), or a GLP-2R antagonist, GLP-2(3-33) (Thulesen et al., 2002; Baldassano et al., 2009) was bolus intravenously injected (3 or 30 $\mathrm{nmol} / \mathrm{kg})$ at $t=10 \mathrm{~min}$, followed by luminal perfusion of L-Glu (10 $\mathrm{mM})$ and IMP $(0.1 \mathrm{mM})$ in $\mathrm{pH} 7.0$ Krebs' solution.

Because the downstream signals of GLP-2R activation may involve the release of VIP and NO (Guan et al., 2006), the effect of the VIP receptor (VIP-R) antagonist VIP(6-28) or the NO synthase inhibitor L-NAME was examined. VIP(6-28) was bolus intravenously injected $(30 \mathrm{nmol} / \mathrm{kg})$ at $t=10 \mathrm{~min}$, followed by luminal perfusion of L-Glu (10 mM) and IMP (0.1 mM) in pH 7.0 Krebs' solution. L-NAME $(0.1 \mathrm{mM})$ was coperfused with L-Glu and IMP with or without L-Arg $(10 \mathrm{mM})$

To further study the mechanisms underlying L-Glu/IMP-induced 
$\mathrm{HCO}_{3}{ }^{-}$secretion, the effect of cyclooxygenase (COX) inhibition, deafferentation, or muscarinic receptor inhibition was examined. Some rats were pretreated with indomethacin (a cyclooxygenase inhibitor, $5 \mathrm{mg} / \mathrm{kg}$ i.p.) $1 \mathrm{~h}$ before or a high dose of capsaicin ( $125 \mathrm{mg} / \mathrm{kg} \mathrm{s.c.)} 10$ to 14 days before the experiments as described previously (Akiba et al., 2009). Atropine ( $1 \mathrm{mg} / \mathrm{kg}$ ) was bolus intravenously injected, followed by luminal perfusion of L-Glu/IMP.

Measurement of GIP, GLP-1, and GLP-2 in Portal Venous Blood. Plasma concentration of GIP, GLP-1, and GLP-2 was measured in the PV blood samples obtained from a PV catheter as described previously (Mizumori et al., 2006). Before preparing the duodenal loop as described above, the gastroduodenal branch of the PV was cannulated with a 23 -gauge metal cannula connected to a PE-50 tube. The catheter was fixed with cyanoacrylate glue, and the tube was filled with heparinized saline, enabling repeated blood sampling. Three samples of PV blood (each $0.2 \mathrm{ml}$ ) were taken followed by flushing with heparinized saline (each $0.2 \mathrm{ml}$ ). We confirmed that the three $0.2-\mathrm{ml}$ blood withdrawals followed by saline flushing did not change blood pressure or body temperature (Mizumori et al., 2006). The samples were collected at the end of the basal period $(t=15 \mathrm{~min})$ and at 15 and $30 \mathrm{~min}$ after luminal perfusion with L-Glu $(10 \mathrm{mM})$ and/or IMP $(0.1 \mathrm{mM})(t=30$ or $45 \mathrm{~min})$ using a syringe containing $1 \mu \mathrm{l}$ each of EDTA $(0.5 \mathrm{mM})$ and dipeptidyl peptidase-IV inhibitor, NVP DPP $728(10 \mu \mathrm{M})$. The samples were immediately centrifuged at $3000 \mathrm{~g}$ for $5 \mathrm{~min}$, and their plasma was stored at $-80^{\circ} \mathrm{C}$ until measurements. Plasma was diluted with Tris$\mathrm{HCl}$ buffer (50 mM, pH 7.4) containing a protease inhibitor cocktail ( $1 \mathrm{mg} / \mathrm{ml}$; Sigma) and NVP DPP $728(10 \mu \mathrm{M})$. Plasma concentration of GIP, GLP-1, and GLP-2 was measured using a rat GIP EIA kit (Phoenix Pharmaceuticals), total GLP-1 enzyme-linked immunosorbent assay kit, or rat GLP-2 EIA kit (ALPCO Diagnostics, Salem, $\mathrm{NH}$ ) according to the manufacturer's protocol. Plasma concentration of VIP in PV blood was also measured using a VIP EIA kit (Bachem California, Torrance, CA).

$\mathrm{NO}$ release into the lumen was measured with an $\mathrm{NO}_{2} / \mathrm{NO}_{3}$ measurement kit (Cayman Chemical, Ann Arbor, MI) based on nitrate conversion to nitrite with nitrate reductase and detection of nitrite by the Griess method. The luminal perfusate was collected every 5 min. Total $\mathrm{NO}_{2} / \mathrm{NO}_{3}$ output was expressed as $\mathrm{NO}_{\mathrm{x}}$ output in the effluent $(\mu \mathrm{mol} / \mathrm{min} / \mathrm{cm})$.

Localization of GIP, GLP, and T1Rs in Rat Duodenum. Immunofluorescence was performed to localize GIP, GLP-1, GLP-2, and T1Rs in rat duodenum. The cryostat sections of the duodenum fixed with $4 \%$ paraformaldehyde were cut at $8 \mu \mathrm{m}$. The sections were incubated with primary antibodies for GIP (Phoenix Pharmaceuticals), GLP-1, GLP-2 (ALPCO Diagnostics), T1R1 (Thermo Fisher Scientific), or T1R3 (Abcam plc, Cambridge, UK), followed by incubation with the corresponding fluorescein isothiocyanate-conjugated secondary antibody (Millipore Bioscience Research Reagents, Temecula, CA). The fluorescence was observed using confocal laser microscopy (LSM-710; Carl Zeiss GmbH, Jena, Germany). Negative controls were examined by omitting the primary antibody.

Statistics. All data are expressed as means \pm S.E.M. Data were derived from six rats in each group. Comparisons between groups were made by one-way analysis of variance followed by Fischer's least-significant difference test. $P$ values of $<0.05$ were taken as significant. The curve fit was performed using Prism (GraphPad Software, Inc., San Diego, CA).

\section{Results}

Effect of Intravenous Infusion of GIP or GLP on Duodenal $\mathrm{HCO}_{3}{ }^{-}$Secretion. Duodenal $\mathrm{HCO}_{3}{ }^{-}$secretion

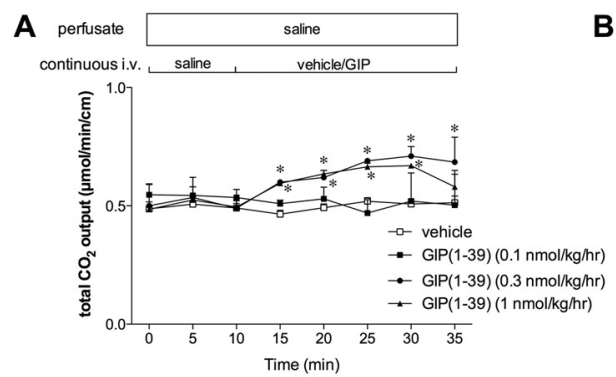

C

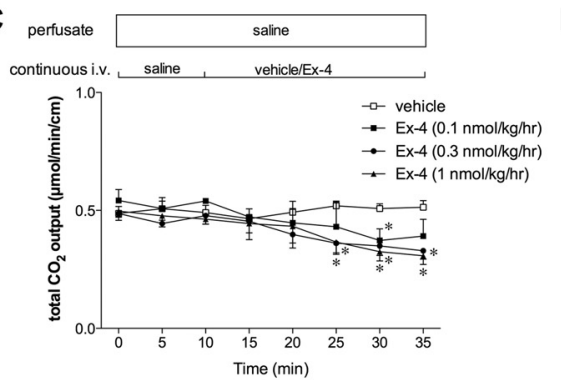

E

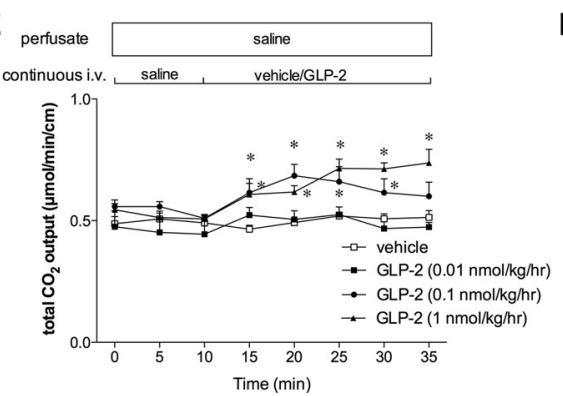

B

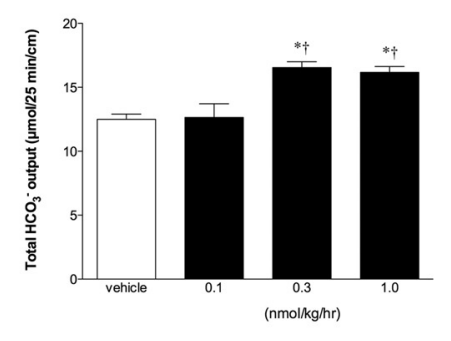

D

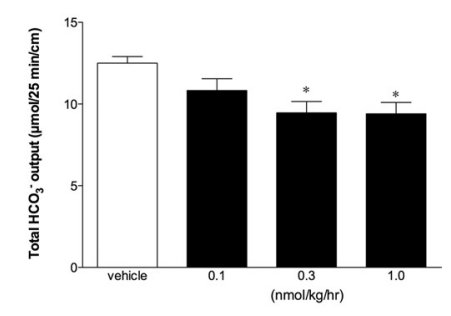

F

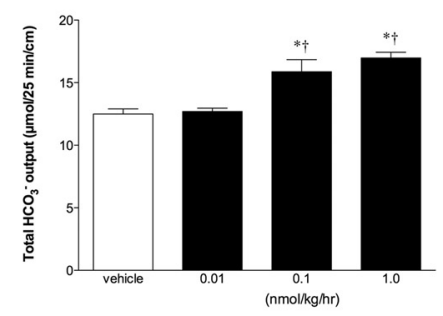

Fig. 1. Effect of intravenous infusion of GIP(1-39), Ex-4, or GLP-2 on duodenal $\mathrm{HCO}_{3}{ }^{-}$secretion in rats. Duodenal $\mathrm{HCO}_{3}{ }^{-}$secretion was measured as total $\mathrm{CO}_{2}$ output using flow-through $\mathrm{pH}$ and $\mathrm{CO}_{2}$ electrodes. Vehicle, $\mathrm{GIP}(1-39)$ $(0.1-1 \mathrm{nmol} / \mathrm{kg} / \mathrm{h})(\mathrm{A}$ and B), Ex-4 (0.1-1 nmol/ $/ \mathrm{kg} / \mathrm{h})(\mathrm{C}$ and $\mathrm{D})$, or GLP-2 $(0.01-1 \mathrm{nmol} / \mathrm{kg} / \mathrm{h})(\mathrm{E}$ and $\mathrm{F})$ was intravenously infused. A, $\mathrm{C}$, and $\mathrm{E}$, total $\mathrm{CO}_{2}$ output over the time course. Each data point represents mean \pm S.E.M. $(n=6$ rats). $*, p<0.05$ versus vehicle group. $\mathrm{B}, \mathrm{D}$, and $\mathrm{F}$, total $\mathrm{HCO}_{3}{ }^{-}$output during the challenge period. Each data point represents mean \pm S.E.M. $(n=6) . *, p<0.05$ versus vehicle group, $\dagger, p<0.05$ versus 0.1 group (B and D) or 0.01 group $(F)$. 
expressed as total $\mathrm{CO}_{2}$ output was stable during duodenal perfusion with $\mathrm{pH} 7.0$ saline and intravenous infusion with saline or vehicle (Fig. 1). Totally secreted $\mathrm{HCO}_{3}{ }^{-}$during the challenge period was calculated and expressed as total $\mathrm{HCO}_{3}{ }^{-}$output $(\mu \mathrm{mol} / 25 \mathrm{~min} / \mathrm{cm})$. Intravenous infusion of GIP(1-39) dose-dependently increased $\mathrm{HCO}_{3}{ }^{-}$secretion (Fig. 1, A and B). Rat GLP-2 also dose-dependently increased $\mathrm{HCO}_{3}{ }^{-}$secretion (Fig. 1, E and F), whereas a GLP-1R agonist, Ex-4, gradually reduced $\mathrm{HCO}_{3}{ }^{-}$secretion (Fig. 1, C and D). These results suggested that exogenous GIP or GLP-2 stimulates whereas GLP-1 mildly suppresses duodenal $\mathrm{HCO}_{3}{ }^{-}$secretion.

Synergistic Effect of L-Glu/IMP on Duodenal $\mathrm{HCO}_{3}{ }^{-}$ Secretion. To confirm the synergism of L-Glu and IMP, the dose response to $\mathrm{L}-\mathrm{Glu}$ or IMP on $\mathrm{HCO}_{3}{ }^{-}$secretion was examined. L-Glu at 1, 10, or $50 \mathrm{mM}$ had little effect, but 100 $\mathrm{mM}$ increased $\mathrm{HCO}_{3}{ }^{-}$secretion (Fig. 2). IMP at $0.1 \mathrm{mM}$ had little effect, but 1 or $10 \mathrm{mM}$ IMP increased $\mathrm{HCO}_{3}{ }^{-}$secretion. Coperfusion of L-Glu (10 or $50 \mathrm{mM}$ ) with IMP $(0.1 \mathrm{mM})$ robustly increased $\mathrm{HCO}_{3}{ }^{-}$secretion, confirming the synergistic effect of L-Glu and IMP.

Effect of Receptor Inhibition of GIP or GLP on L-Glu/ IMP-Induced Duodenal $\mathbf{H C O}_{\mathbf{3}}{ }^{-}$Secretion. Luminal coperfusion of L-Glu (10 mM) and IMP $(0.1 \mathrm{mM})$ after a bolus intravenous injection of vehicle increased duodenal $\mathrm{HCO}_{3}{ }^{-}$ secretion as reported previously (Akiba et al., 2009). A bolus intravenous injection of the GIP-R antagonist Pro ${ }^{3}$ GIP (30 $\mathrm{nmol} / \mathrm{kg})$ or the GLP-1R antagonist Ex-3(9-39) (30 nmol/kg) had no effect on L-Glu/IMP-induced $\mathrm{HCO}_{3}{ }^{-}$secretion (Fig. 3, $\mathrm{A}$ and $\mathrm{B})$. In contrast, a GLP-2R antagonist, GLP-2(3-33) (3 $\mathrm{nmol} / \mathrm{kg}$ i.v.), inhibited L-Glu/IMP-induced $\mathrm{HCO}_{3}{ }^{-}$secretion (Fig. 3C), suggesting that L-Glu/IMP-induced $\mathrm{HCO}_{3}{ }^{-}$secretion is mediated by GLP-2R activation.

Because GLP-2(3-33) is a partial agonist for GLP-2R (Thulesen et al., 2002), we confirmed the inhibitory effect of GLP-2(3-33) on GLP-2-induced $\mathrm{HCO}_{3}{ }^{-}$secretion. A bolus intravenous injection of GLP-2(3-33) (3 nmol/ $/ \mathrm{kg})$ inhibited GLP-2 (0.1 nmol/kg/h)-induced $\mathrm{HCO}_{3}{ }^{-}$secretion (Fig. 4A), whereas GLP-2(3-33) (3 nmol/kg i.v.) alone had a small effect on $\mathrm{HCO}_{3}{ }^{-}$secretion (Fig. 4B), confirming GLP-2(3-33) as a partial agonist.

Effect of Luminal Perfusion of L-Glu and/or IMP on GIP or GLP Release into PV. Because we have reported

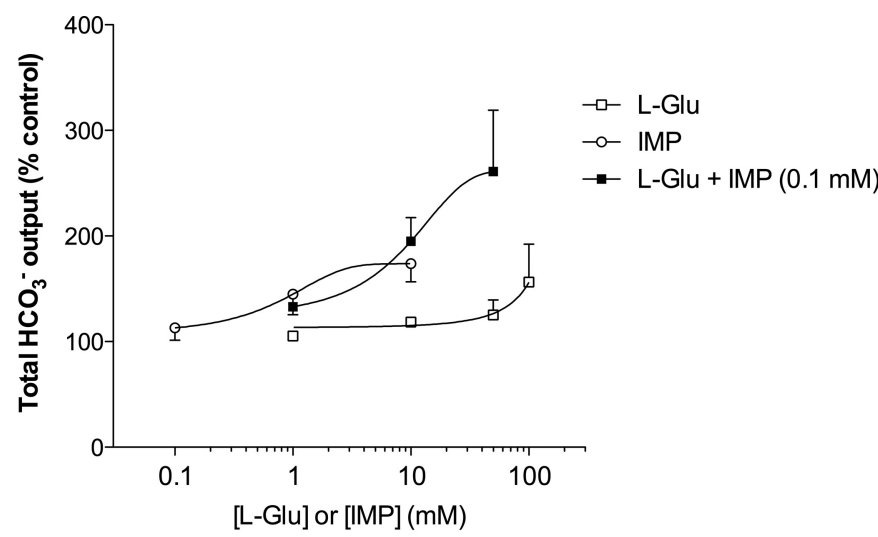

Fig. 2. Dose response of $\mathrm{HCO}_{3}{ }^{-}$secretion to luminal perfusion of L-Glu and/or IMP in rat duodenum. Total $\mathrm{HCO}_{3}{ }^{-}$output $(\mu \mathrm{mol} / 25 \mathrm{~min} / \mathrm{cm})$ during the challenge period in L-Glu, IMP, or L-Glu + IMP group was compared with Krebs alone perfusion group and expressed as percentage of control. Each data point represents mean \pm S.E.M. $(n=2-6)$.
A
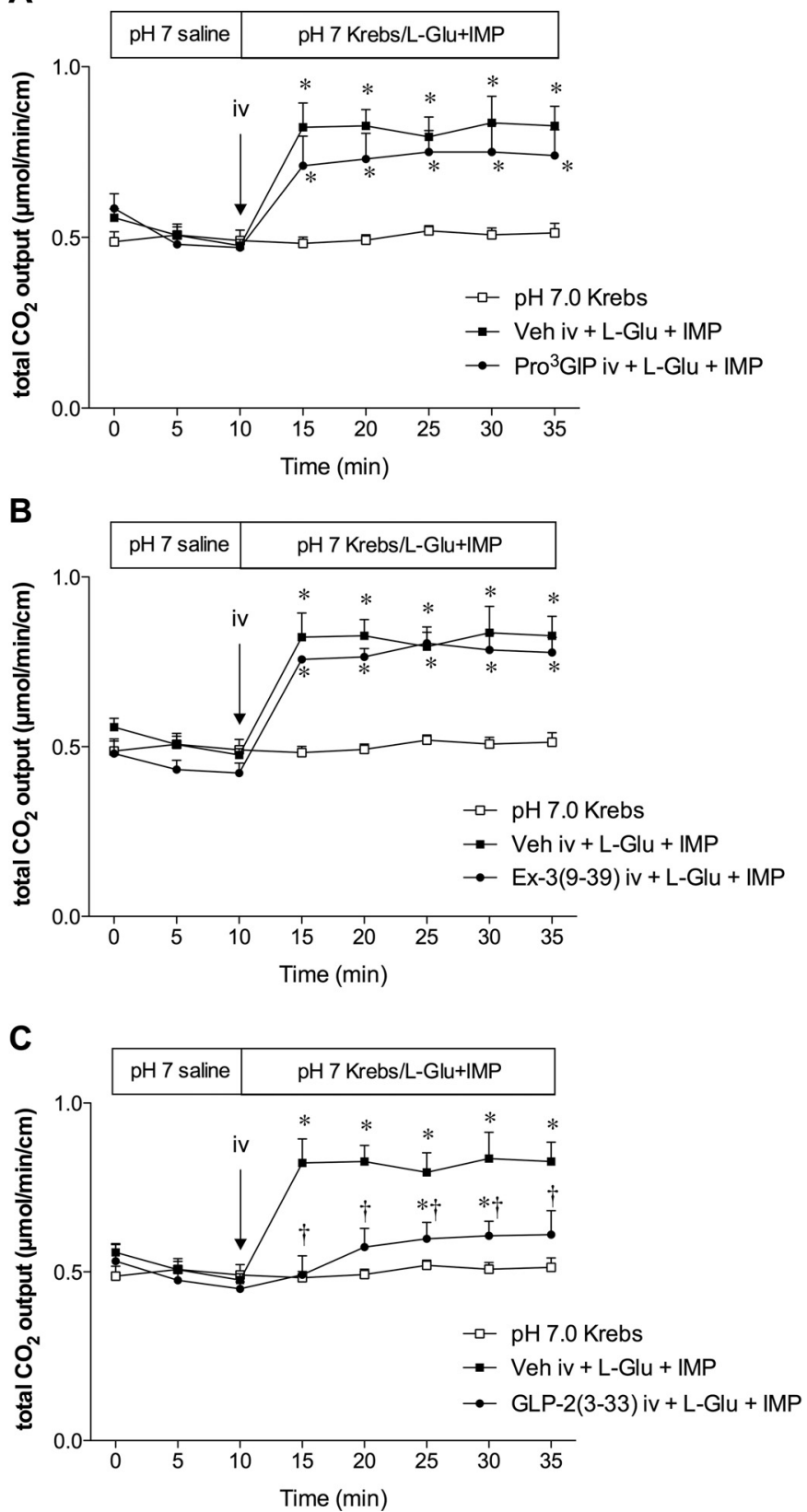

Fig. 3. Effect of receptor inhibitor of GIP, GLP-1, or GLP-2 on L-Glu/IMPinduced $\mathrm{HCO}_{3}{ }^{-}$secretion in rat duodenum. Vehicle (Veh), Pro ${ }^{3} \mathrm{GIP}$ (30 $\mathrm{nmol} / \mathrm{kg})(\mathrm{A})$, Ex-3(9-39) (30 nmol/kg) (B), or GLP-2(3-33) $(3 \mathrm{nmol} / \mathrm{kg})(\mathrm{C})$ was bolus intravenously injected at $t=10 \mathrm{~min}$ followed by luminal coperfusion of L-Glu $(10 \mathrm{mM})$ and IMP $(0.1 \mathrm{mM})$. Each data point represents mean \pm S.E.M. $(n=6$ rats $) ., p<0.05$ versus $\mathrm{pH} 7.0$ Krebs group. $\dagger, p<0.05$ versus intravenous vehicle + L-Glu + IMP group.

that luminal coperfusion of L-Glu and IMP stimulates duodenal $\mathrm{HCO}_{3}{ }^{-}$secretion, possibly via the activation of T1R1/R3 expressed in the duodenal mucosa (Akiba et al., 2009), and because T1R2/R3 activation increases incretin release (Jang et al., 2007), we measured PV plasma concentrations of GIP and GLP before and after luminal perfusion of T1R1/R3 ligands L-Glu and/or IMP. Stable PV concentrations of GIP, GLP-1, and GLP-2 were observed during luminal perfusion of $\mathrm{pH} 7.0 \mathrm{Krebs}$ as a control group (Fig. 5). Luminal perfusion of L-Glu (10 mM), IMP $(0.1 \mathrm{mM})$, or both had no effect on PV GIP concentration (Fig. 5A). L-Glu or IMP alone 
A

perfusate saline

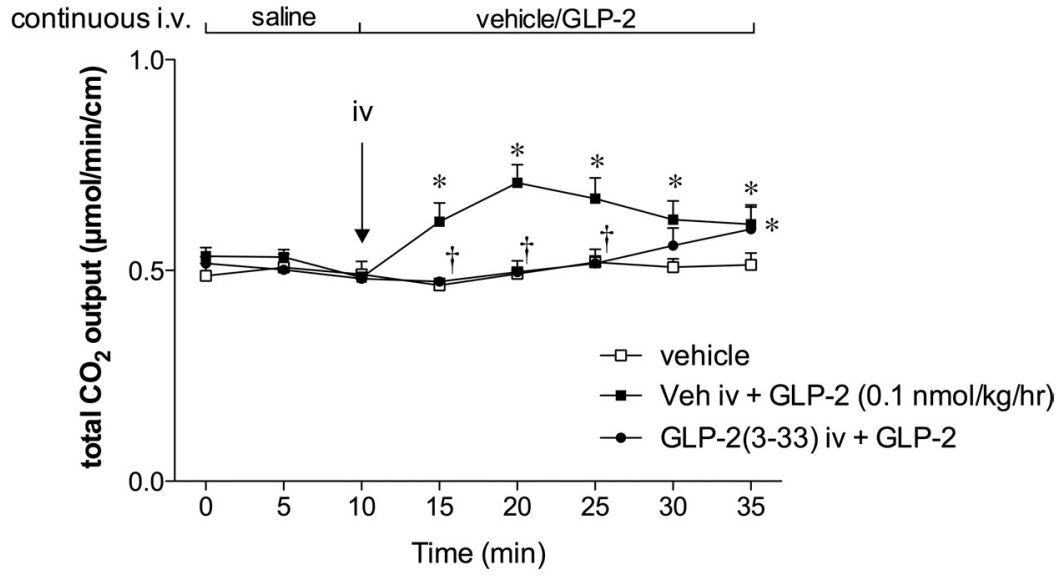

B

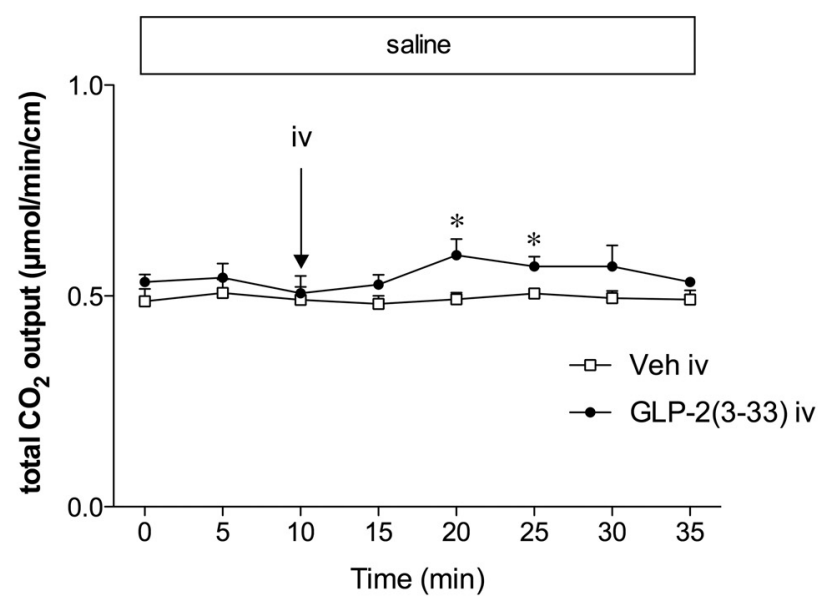

had no effect, but L-Glu/IMP increased PV GLP-1 concentration only at $t=45 \mathrm{~min}$ (Fig. 5B). In contrast, luminal L-Glu or IMP alone transiently increased PV GLP-2 concentration, whereas L-Glu/IMP continuously and synergistically increased PV GLP-2 concentration (Fig. 5C), suggesting that luminal L-Glu/IMP increases GLP-2 release followed by GLP-1 release into the PV.

Localization of GIP, GLP-1, GLP-2, and T1Rs in Rat Duodenal Mucosa. GIP-, GLP-1-, or GLP-2-like immunoreactivity was recognized in the endocrine-like cells in the duodenum (Fig. 6, A-C). Furthermore, T1R1- or T1R3-like immunoreactivity was also observed in the endocrine-like cells (Fig. 6, D and E). These observations were consistent with previous reports of the duodenum or jejunum (Theodorakis et al., 2006; Jang et al., 2007; Mace et al., 2007), supporting our hypothesis that the activation of T1R1/R3 by luminal compounds may release GIP or GLP from the corresponding endocrine cells in rat duodenum.

Effect of VIP(6-28) or L-NAME on L-Glu/IMP-Induced Duodenal $\mathrm{HCO}_{3}{ }^{-}$Secretion. To further investigate the downstream signals of L-Glu and IMP after GLP-2R activation, we examined the effect of a VIP-R antagonist or an NO synthase inhibitor on L-Glu/IMP-induced $\mathrm{HCO}_{3}{ }^{-}$secretion. A bolus intravenous injection of $\operatorname{VIP}(6-28)(30 \mathrm{nmol} / \mathrm{kg})$ inhibited L-Glu/IMP-induced $\mathrm{HCO}_{3}{ }^{-}$secretion (Fig. 7A). Coperfu-
Fig. 4. Effect of intravenous GLP-2(3-33) on GLP-2-induced $\mathrm{HCO}_{3}{ }^{-}$secretion in rat duodenum. GLP-2(3-33) (3 $\mathrm{nmol} / \mathrm{kg}$ ) was bolus intravenously injected at $t=10 \mathrm{~min}$ followed by continuous intravenous infusion of GLP-2 (0.1 $\mathrm{nmol} / \mathrm{kg} / \mathrm{h}$ ) (A) or saline (B). Each data point represents mean \pm S.E.M. $(n=6$ rats). $*, p<0.05$ versus vehicle group or intravenous vehicle group. $\dagger, p<0.05$ versus intravenous vehicle + GLP-2 group. sion of L-NAME $(0.1 \mathrm{mM})$ with L-Glu/IMP also inhibited L-Glu/IMP-induced $\mathrm{HCO}_{3}{ }^{-}$secretion, whereas the addition of L-Arg $(10 \mathrm{mM})$ in the perfusate reversed the inhibitory effect of L-NAME (Fig. 7B). We also measured VIP plasma concentration in PV blood and NO release into the lumen. Luminal perfusion of L-Glu/IMP increased VIP concentrations in PV (Fig. 8A). $\mathrm{NO}_{\mathrm{x}}$ output in the effluents was gradually increased during L-Glu/IMP perfusion (Fig. 8B). Both VIP and NO release in response to luminal L-Glu/IMP were abolished by GLP-2(3-33) (3 nmol/kg i.v.), confirming that the release of VIP and NO is downstream of GLP-2R activation. These results suggest that the stimulatory effect of luminal L-Glu/ IMP on $\mathrm{HCO}_{3}{ }^{-}$secretion includes the release of VIP and NO after GLP-2R activation, similar to a published report (Guan et al., 2006).

Effect of COX Inhibition, Deafferentation, or Muscarinic Receptor Inhibition on L-Glu/IMP-Induced Duodenal $\mathrm{HCO}_{3}{ }^{-}$Secretion. To investigate whether prostaglandin (PG) synthesis, afferent nerves, or vagal efferent nerves are involved in the effect of L-Glu/IMP, we examined the effect of indomethacin pretreatment, capsaicin pretreatment, or atropine intravenous injection, respectively, on LGlu/IMP-induced $\mathrm{HCO}_{3}{ }^{-}$secretion. Indomethacin pretreatment $(5 \mathrm{mg} / \mathrm{kg}$ i.p.) had no effect on the initial increase in $\mathrm{HCO}_{3}{ }^{-}$secretion, but inhibited the sustained increase of 

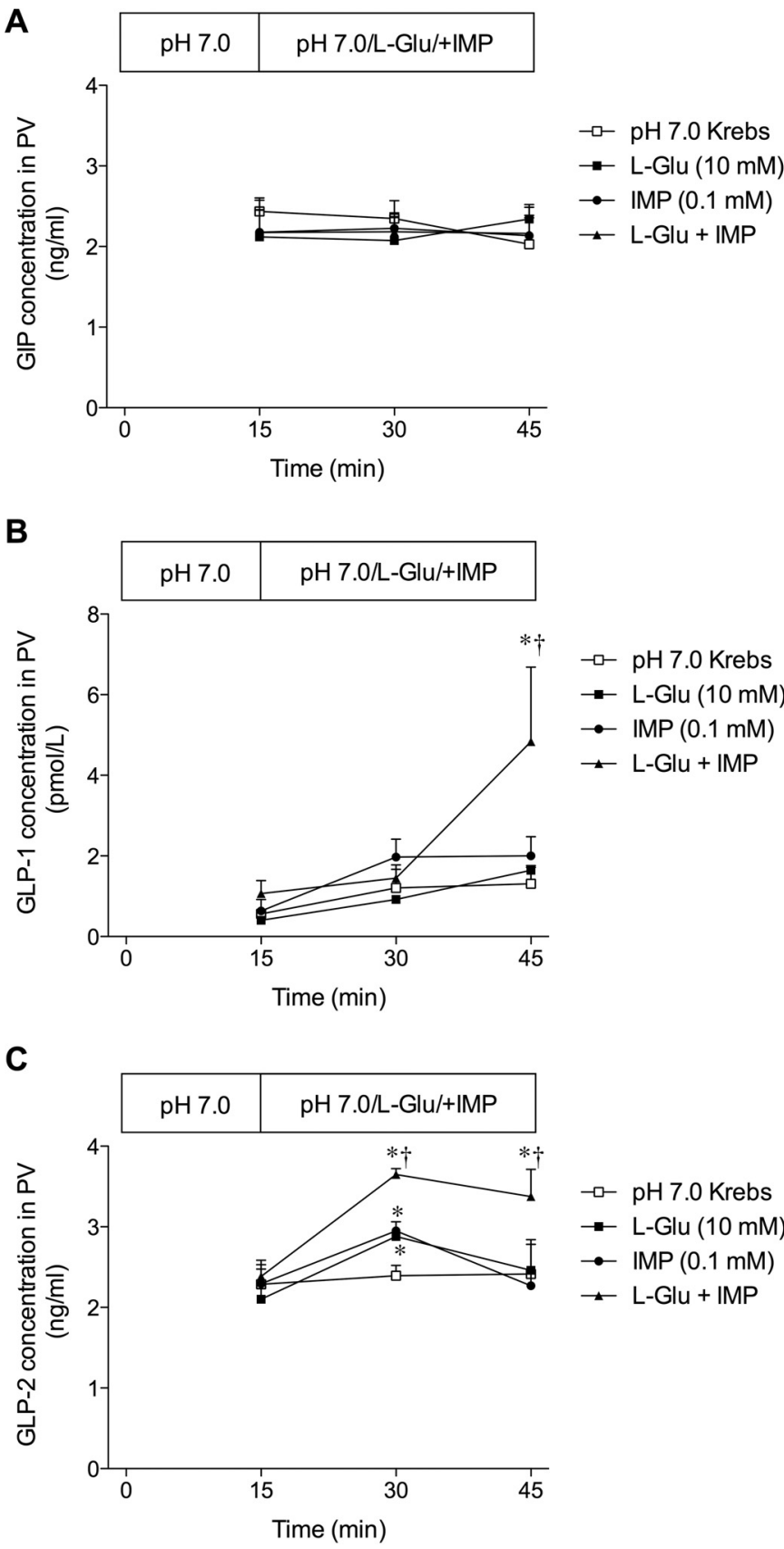

Fig. 5. Effect of luminal perfusion with L-Glu and/or IMP on the release of GIP, GLP-1, or GLP-2 into PV. PV blood was collected before and after luminal perfusion of L-Glu $(10 \mathrm{mM})$, IMP $(0.1 \mathrm{mM})$, or both. Plasma concentration of GIP (A), GLP-1 (B), or GLP-2 (C) was measured. Each data point represents mean \pm S.E.M. $(n=6$ rats $) *, p<0.05$ versus $\mathrm{pH}$ 7.0 Krebs group. $\dagger, p<0.05$ versus L-Glu group.

$\mathrm{HCO}_{3}{ }^{-}$secretion during L-Glu/IMP perfusion (Fig. 9A), suggesting that the COX-PG pathway is involved in the later period of $\mathrm{L}-\mathrm{Glu} / \mathrm{IMP}$-induced $\mathrm{HCO}_{3}{ }^{-}$secretion. Capsaicin pretreatment $(125 \mathrm{mg} / \mathrm{kg}$ s.c.) or atropine $(1 \mathrm{mg} / \mathrm{kg}$ i.v. $)$ had no effect on the L-Glu/IMP-induced $\mathrm{HCO}_{3}{ }^{-}$secretion (Fig. 9, $\mathrm{B}$ and $\mathrm{C}$ ), suggesting that the afferent-vagal efferent reflex is not likely to be involved in the mechanism.

\section{Discussion}

We demonstrated for the first time that GLP-2 is a secretagogue for duodenal $\mathrm{HCO}_{3}{ }^{-}$secretion in vivo and luminal
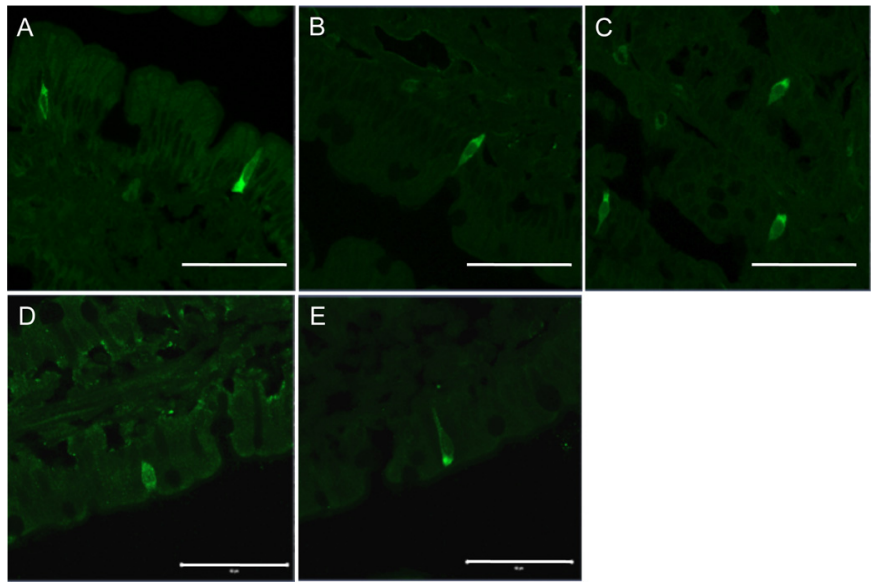

Fig. 6. Expression of GIP, GLP-1, GLP-2, and taste receptors in rat duodenum. The cryostat sections of duodenum were immunostained with antibodies for GIP (A), GLP-1 (B), GLP-2 (C), T1R1 (D), or T1R3 (E). Scale bars, $50 \mu \mathrm{m}$.

L-Glu/IMP-induced $\mathrm{HCO}_{3}{ }^{-}$secretion is mediated by GLP-2 release and GLP-2R activation followed by VIP and NO release. The incretin, GIP, which is also a secretagogue (Flemström et al., 1982; Konturek et al., 1985), and the incretin GLP-1, which is coreleased with GLP-2 from L cells (Orskov et al., 1986), were not involved in L-Glu/IMP-related duodenal $\mathrm{HCO}_{3}{ }^{-}$secretion. This study suggests that umami receptor activation by luminal amino acids protects the duodenal mucosa from injury through the stimulation of protective $\mathrm{HCO}_{3}{ }^{-}$secretion. Furthermore, because GLP-2 is an intestinotrophic hormone (Tsai et al., 1997), increased GLP-2 release by luminal amino acids may accelerate repair of damaged intestinal epithelium. Concomitant release of GLP-1 may also improve glucose metabolism.

We showed that intravenous infusion of GLP-2 increased duodenal $\mathrm{HCO}_{3}{ }^{-}$secretion. GIP infusion also increased $\mathrm{HCO}_{3}{ }^{-}$secretion, consistent with previous reports (Flemström et al., 1982; Konturek et al., 1985), whereas GLP-1 infusion was inhibitory. In Ussing-chambered guinea pig ileum, GLP-2 itself has no effect on anion secretion, but suppressed neurally evoked anion secretion (Baldassano et al., 2009), inconsistent with our results, whereas GLP-2 effects were inhibited by GLP-2(3-33) and a VIP-R antagonist, consistent with our results. The discrepancy may be explained by differences in species, intestinal segments, and preparation. We also confirmed that GLP-2(3-33) antagonized the GLP-2 receptor and GLP-2(3-33) alone had only a small effect on $\mathrm{HCO}_{3}{ }^{-}$secretion, because GLP-2(3-33) is a partial agonist (Thulesen et al., 2002).

We reported previously that luminal L-Glu enhances duodenal mucosal defense mechanisms via multiple pathways including metabotropic glutamate receptors and T1R1/R3, whereas calcium-sensing receptor activation produced somewhat discordant effects (Akiba et al., 2009). Bicarbonate secretion is one of the most important and most-studied duodenal defense mechanisms (Allen and Flemström, 2005). Although individual amino acids or metabotropic glutamate receptor agonists have no effect on $\mathrm{HCO}_{3}{ }^{-}$secretion, coperfusion of an amino acid with IMP synergistically increases $\mathrm{HCO}_{3}{ }^{-}$secretion (Akiba et al., 2009). We also examined the dose response of L-Glu and IMP. L-Glu obviously increased $\mathrm{HCO}_{3}{ }^{-}$secretion only at $100 \mathrm{mM}$, whereas the addition of 

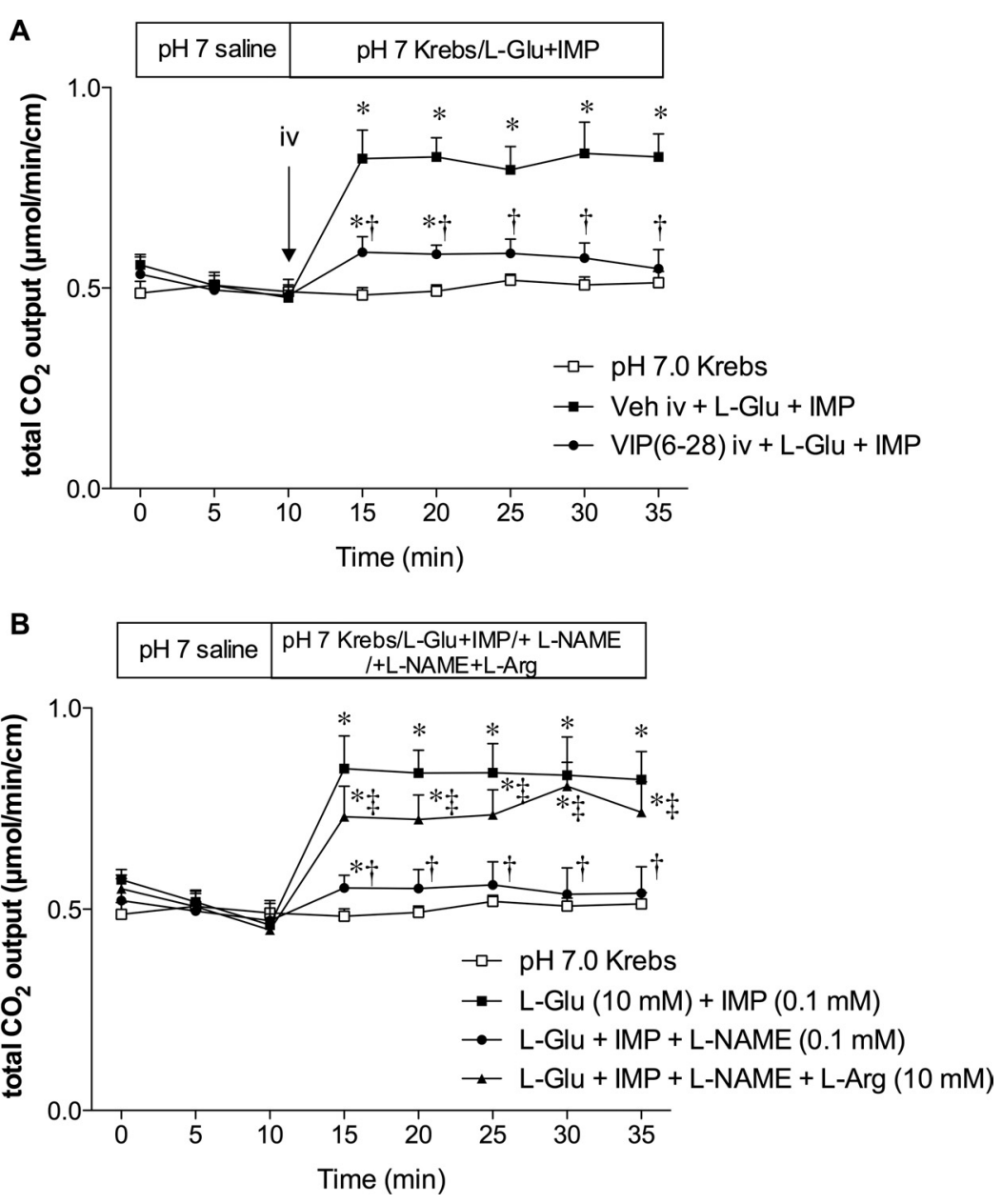

Fig. 7. Effect of intravenous VIP(6-28) or L-NAME coperfusion on L-Glu/IMP-induced $\mathrm{HCO}_{3}{ }^{-}$secretion in rat duodenum. A, VIP(6-28) (30 nmol/kg) was bolus intravenously injected at $t=10 \mathrm{~min}$ followed by luminal perfusion of L-Glu $(10 \mathrm{mM})$ and IMP $(0.1 \mathrm{mM})$. Each data point represents mean \pm S.E.M. $(n=6$ rats $) . *, p<0.05$ versus $\mathrm{pH} 7.0$ Krebs group. $\dagger, p<0.05$ versus vehicle (Veh) intravenous + L-Glu + IMP group. B, L-NAME $(0.1 \mathrm{mM})$ with or without L-Arg $(10 \mathrm{mM})$ was luminally coperfused with L-Glu and IMP. Each data point represents mean \pm S.E.M. $(n=6$ rats $)$ *, $p<0.05$ versus $\mathrm{pH} 7.0$ Krebs group. $\dagger, p<0.05$ versus L-Glu + IMP group. $\ddagger, p<0.05$ versus L-Glu + IMP + L-NAME group.
IMP at $0.1 \mathrm{mM}$, which alone had little effect, to L-Glu at 10 or $50 \mathrm{mM}$ markedly increased $\mathrm{HCO}_{3}{ }^{-}$secretion, confirming the synergism. Synergism with nucleotide monophosphates is characteristic of activation of the umami T1R1/R3 taste receptor due to a cooperative binding site for L-Glu and IMP on the Venus flytrap domain of T1R1 (Zhang et al., 2008), supporting our hypothesis that L-Glu/IMP-induced $\mathrm{HCO}_{3}{ }^{-}$secretion is mediated by umami receptor activation. IMP at higher doses also increased $\mathrm{HCO}_{3}{ }^{-}$secretion with increased ATP output (data not shown), possibly including the ATPP2Y pathway, because IMP may competitively inhibit intestinal alkaline phosphatase as reported previously (Mizumori et al., 2009).

Expression of $\mathrm{T} 1 \mathrm{Rs}$ in the gastrointestinal mucosa or enteroendocrine cells is still controversial. T1R1 and T1R3 are immunolocalized on the brush border of villous epithelial cells and in the endocrine cells of proximal intestine (Jang et al., 2007; Mace et al., 2007). We also localized T1R1- and T1R3-positive cells of endocrine-like morphology to rat duodenum. Furthermore, the related sweet taste receptor T1R2/R3 heterodimer is expressed in GLP-1-positive L cells, implicated in sweet taste receptor-mediated GLP-1 release (Margolskee et al., 2007). Single L-amino acids, including L-Glu, increased GLP-1 release from cultured enteroendocrine-like GLUTag cells (Reimann et al., 2004). In humans, oral glutamine increased circulating GLP-1 concentration at similar concentrations to oral glucose (Greenfield et al., 2009). In contrast, purified L cells from transgenic mice with green fluorescent protein-tagged proglucagon gene promoter have low expression of T1R1, T1R2, and T1R3, similar to the low expression on lingual taste buds (Reimann et al., 2008). Artificial sweeteners, which serve as high-affinity T1R2/R3 ligands, fail to release GLP-1 in rats in vivo, in humans, and from purified L cells (Reimann et al., 2008; Fujita et al., 2009; Little et al., 2009; Ma et al., 2009), demonstrating that glucose sensing in L cells is not likely mediated by T1R2/R3. Furthermore, L-Glu meal supplementation had no effect on circulating postprandial plasma concentrations of glucose, insulin, glucagon, or GLP-1 in humans (Boutry et al., 2011). Although glucose-induced GLP-1 release is probably mediated by the sodium-glucose cotransporter SGLT1 in L cells, rather than by the T1R2/R3 sweet receptor, our finding that luminal L-Glu/IMP releases GLP-2 via T1R1/R3 activation remains possible. The discrepancy may be explained by the species differences or different route of application (i.e., oral, intragastric, or intraduodenal).

The source of GLP-2 is also controversial. The early postprandial rise of GLP-1 plasma concentration within 10 to 15 min of food ingestion is explained by a proximal-distal loop in which luminal nutrient detection in the proximal intestine regulates GLP-1 release from distal $L$ cells via the neuronal or hormonal pathways, because L cell density is low in the proximal intestine (Brubaker and Anini, 2003). Nevertheless, $\mathrm{L}$ cell density in the human duodenum is adequate to explain the early phase of GLP-1 secretion (Theodorakis et al., 2006). We also confirmed the presence of GLP-1 and 


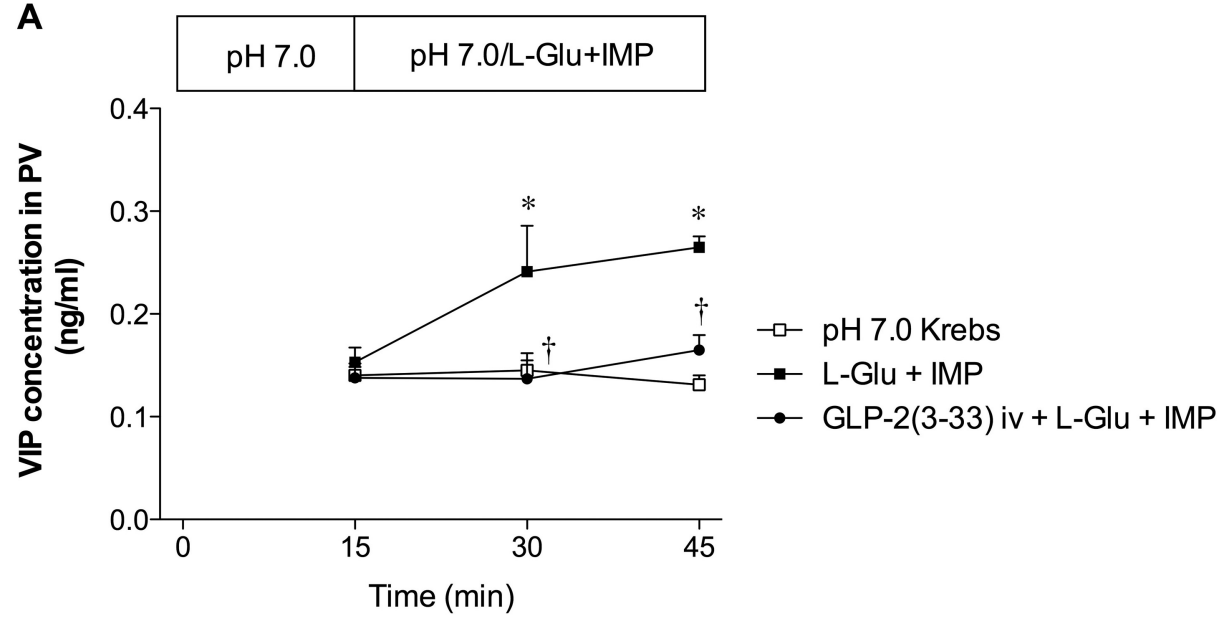

B

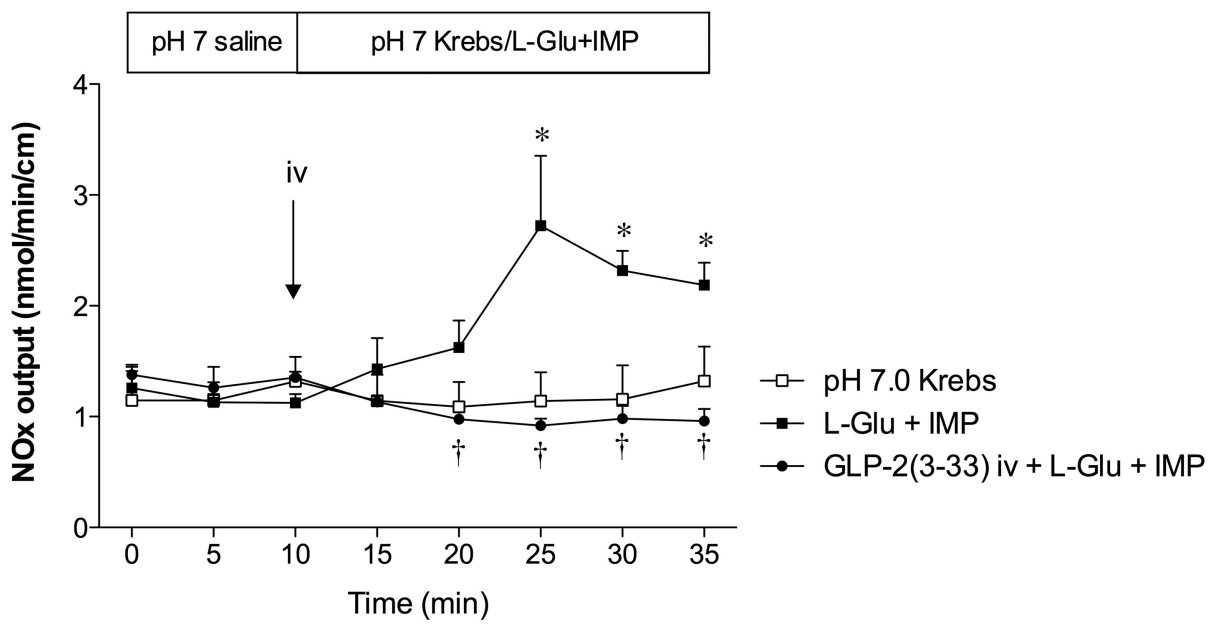

Fig. 8. Effect of luminal perfusion with L-Glu/IMP on release of VIP or NO. VIP concentration in PV blood (A) or luminal content of $\mathrm{NO}_{\mathrm{x}}$ in the effluent (B) was measured before and after luminal perfusion of L-Glu $(10 \mathrm{mM})$ and IMP $(0.1 \mathrm{mM})$ with or without a bolus intravenous injection of GLP-2(3-33) (3 nmol/ $\mathrm{kg})$. Each data point represents mean \pm S.E.M. $(n=3-6$ rats). $*, p<0.05$ versus $\mathrm{pH} 7.0$ Krebs group. $\dagger, p<0.05$ versus L-Glu + IMP group.
GLP-2 immunoreactive endocrine-like cells in rat duodenum. Furthermore, L-Glu/IMP-induced $\mathrm{HCO}_{3}{ }^{-}$secretion was not affected by treatment with atropine or selective deafferentation with high-dose capsaicin, suggesting that locally released GLP-2 in the perfused duodenum may stimulate $\mathrm{HCO}_{3}{ }^{-}$secretion. Yet, GLP-2 release from distal intestinal L cells via cholecystokinin release from the proximal I cells remains possible, because cholecystokinin releases peptide YY from colonic L cells (Greeley et al., 1989).

GLP-2 activates GLP-2R, which are expressed on myenteric neurons and endocrine cells (Guan et al., 2006). GLP2-induced mesenteric hyperemia is mediated by VIP and NO (Guan et al., 2006), suggesting that released GLP-2 activates GLP-2R expressed on myenteric neurons, releasing VIP or $\mathrm{NO}$, which increases $\mathrm{HCO}_{3}{ }^{-}$secretion via the cellular cAMP or cGMP pathways, respectively, as reported previously (Yao et al., 1993; Takeuchi et al., 2011). These pathways are consistent with our results that L-Glu/IMP-induced $\mathrm{HCO}_{3}{ }^{-}$ secretion was inhibited by a GLP-2R antagonist, a VIP-R antagonist, and an NO synthase inhibitor. Enhancement of $\mathrm{HCO}_{3}{ }^{-}$secretion through VIP release is similar to a mechanism postulated in a prior report in which a VIP-R antagonist impaired acid-induced $\mathrm{HCO}_{3}{ }^{-}$secretion (Takeuchi et al., 1998). Furthermore, VIP release in PV was increased by luminal L-Glu/IMP, followed by increased luminal $\mathrm{NO}_{\mathrm{x}}$ output, and both were inhibited by a GLP-2R antagonist, suggesting that VIP released from VIP-positive myenteric neu- rons via GLP-2R activation stimulates VIP-R on NO synthase-positive neurons, which release NO. Direct contribution of VIP and $\mathrm{NO}$ to $\mathrm{HCO}_{3}{ }^{-}$secretion from epithelial cells is still unclear. Interaction between VIP and NO in the regulation of duodenal $\mathrm{HCO}_{3}{ }^{-}$secretion will be further clarified, as reported for fluid secretion in jejunum (Mourad et al., 2003). COX inhibition inhibited L-Glu/IMP effects only during the late period. Because NO increases PGs release (Takeuchi et al., 2011), release of PGs in response to NO release may affect the sustained increase of $\mathrm{HCO}_{3}{ }^{-}$secretion during L-Glu/IMP perfusion.

GLP-2 increases intestinal mass and villous height due to increased epithelial cell proliferation (Tsai et al., 1997). GLP-2 or its stable analog teduglitide is hence used for the treatment of short bowel syndrome (Jeppesen et al., 2011). Furthermore, exogenous GLP-2 prevents experimental enteritis or colitis in animal models (Boushey et al., 1999; Drucker et al., 1999) and has also been used clinically to treat Crohn's disease (Buchman et al., 2010). Our results suggest that luminal nutrients such as amino acids increase GLP-2 release, which may prevent and repair intestinal injury. The intestinotrophic action of GLP-2 is potentiated by enteral nutrients, which increase plasma GLP-2 concentrations (Liu et al., 2008), supporting our hypothesis.

In conclusion, the mechanisms of L-Glu/IMP-induced duodenal $\mathrm{HCO}_{3}{ }^{-}$secretion involve GLP-2 release and GLP-2R activation, followed by VIP and NO release. Luminal nutri- 

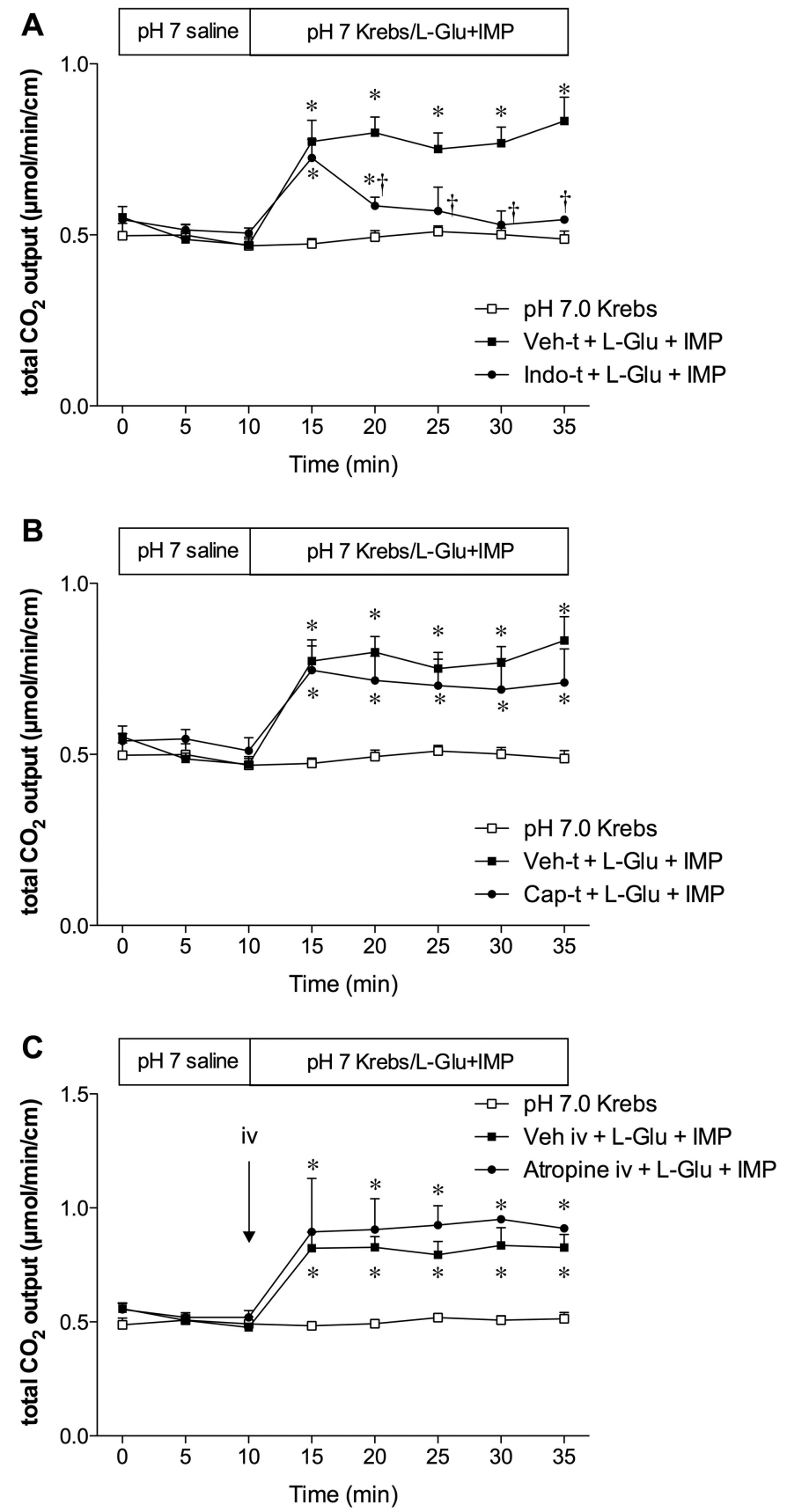

Fig. 9. Effect of cyclooxygenase inhibition, deafferentation, or atropine on L-Glu/IMP-induced $\mathrm{HCO}_{3}{ }^{-}$secretion in rat duodenum. Rats were pretreated with vehicle (Veh-t), indomethacin (Indo-t), or capsaicin (Cap-t) or intravenously injected with vehicle or atropine $(1 \mathrm{mg} / \mathrm{kg})$. Indo-t partially inhibited L-Glu/IMP-induced $\mathrm{HCO}_{3}{ }^{-}$secretion, whereas Cap-t (B) or intravenous atropine $(\mathrm{C})$ had no effect. Each data point represents mean \pm S.E.M. $(n=6$ rats $) . *, p<0.05$ versus $\mathrm{pH} 7.0$ Krebs group. $\dagger, p<$ 0.05 versus Veh-t + L-Glu + IMP group.

ent receptor activation, including the umami receptor, may protect the intestinal mucosa by enhancing $\mathrm{HCO}_{3}{ }^{-}$secretion, in addition to the intestinotrophic effects of GLP-2 and the insulinotropic effects of GLP-1.

\section{Acknowledgments}

We thank Coleen Palileo for assistance with manuscript preparation.

\section{Authorship Contributions}

Participated in research design: Kaunitz and Akiba.

Conducted experiments: Wang, Inoue, Higashiyama, and Akiba.

Performed data analysis: Wang, Inoue, Higashiyama, Guth, Engel, Kaunitz, and Akiba.

Wrote or contributed to the writing of the manuscript: Wang, Kaunitz, and Akiba.

\section{References}

Akiba Y and Kaunitz JD (2011) Duodenal chemosensing and mucosal defenses. Digestion 83(Suppl 1):25-31.

Akiba Y, Mizumori M, Guth PH, Engel E, and Kaunitz JD (2007) Duodenal brush border intestinal alkaline phosphatase activity affects bicarbonate secretion in rats. Am J Physiol Gastrointest Liver Physiol 293:G1223-G1233.

Akiba Y, Watanabe C, Mizumori M, and Kaunitz JD (2009) Luminal L-glutamate enhances duodenal mucosal defense mechanisms via multiple glutamate receptors in rats. Am J Physiol Gastrointest Liver Physiol 297:G781-G791.

Allen A and Flemström G (2005) Gastroduodenal mucus bicarbonate barrier: protection against acid and pepsin. Am J Physiol Cell Physiol 288:C1-C19.

Amato A, Baldassano S, Serio R, and Mulè F (2009) Glucagon-like peptide-2 relaxes mouse stomach through vasoactive intestinal peptide release. Am J Physiol Gastrointest Liver Physiol 296:G678-G684.

Baldassano S, Liu S, Qu MH, Mulè F, and Wood JD (2009) Glucagon-like peptide-2 modulates neurally evoked mucosal chloride secretion in guinea pig small intestine in vitro. Am J Physiol Gastrointest Liver Physiol 297:G800-G805.

Boushey RP, Yusta B, and Drucker DJ (1999) Glucagon-like peptide 2 decreases mortality and reduces the severity of indomethacin-induced murine enteritis. Am J Physiol Endocrinol Metab 277:E937-E947.

Boutry C, Matsumoto H, Airinei G, Benamouzig R, Tomé D, Blachier F, and Bos C (2011) Monosodium glutamate raises antral distension and plasma amino acid after a standard meal in humans. Am J Physiol Gastrointest Liver Physiol 300: G137-G145.

Brubaker PL and Anini Y (2003) Direct and indirect mechanisms regulating secretion of glucagon-like peptide-1 and glucagon-like peptide-2. Can J Physiol Pharmacol 81:1005-1012.

Buchman AL, Katz S, Fang JC, Bernstein CN, Abou-Assi SG, and Teduglutide Study Group (2010) Teduglutide, a novel mucosally active analog of glucagon-like peptide-2 (GLP-2) for the treatment of moderate to severe Crohn's disease. Inflamm Bowel Dis 16:962-973.

Drucker DJ, Yusta B, Boushey RP, DeForest L, and Brubaker PL (1999) Human $\left[\mathrm{Gly}^{2}\right]$ GLP-2 reduces the severity of colonic injury in a murine model of experimental colitis. Am J Physiol Gastrointest Liver Physiol 276:G79-G91.

Engelstoft MS, Egerod KL, Holst B, and Schwartz TW (2008) A gut feeling for obesity: 7TM sensors on enteroendocrine cells. Cell Metab 8:447-449.

Flemström G, Garner A, Nylander O, Hurst BC, and Heylings JR (1982) Surface epithelial $\mathrm{HCO}_{3}{ }^{-}$transport by mammalian duodenum in vivo. Am $\mathrm{J}$ Physiol Gastrointest Liver Physiol 243:G348-G358.

Fujita Y, Wideman RD, Speck M, Asadi A, King DS, Webber TD, Haneda M, and Kieffer TJ (2009) Incretin release from gut is acutely enhanced by sugar but not by sweeteners in vivo. Am J Physiol Endocrinol Metab 296:E473-E479.

Gault VA, Irwin N, Green BD, McCluskey JT, Greer B, Bailey CJ, Harriott P, O'harte FP, and Flatt PR (2005) Chemical ablation of gastric inhibitory polypeptide receptor action by daily $\left(\mathrm{Pro}^{3}\right.$ )GIP administration improves glucose tolerance and ameliorates insulin resistance and abnormalities of islet structure in obesityrelated diabetes. Diabetes 54:2436-2446.

Göke R, Fehmann HC, Linn T, Schmidt H, Krause M, Eng J, and Göke B (1993) Exendin-4 is a high potency agonist and truncated exendin-(9-39)-amide an antagonist at the glucagon-like peptide 1-(7-36)-amide receptor of insulin-secreting $\beta$-cells. J Biol Chem 268:19650-19655.

Greeley GH Jr, Jeng YJ, Gomez G, Hashimoto T, Hill FL, Kern K, Kurosky T, Chuo HF, and Thompson JC (1989) Evidence for regulation of peptide-YY release by the proximal gut. Endocrinology 124:1438-1443.

Greenfield JR, Farooqi IS, Keogh JM, Henning E, Habib AM, Blackwood A, Reimann F, Holst JJ, and Gribble FM (2009) Oral glutamine increases circulating glucagonlike peptide 1 , glucagon, and insulin concentrations in lean, obese, and type 2 diabetic subjects. Am J Clin Nutr 89:106-113.

Guan X, Karpen HE, Stephens J, Bukowski JT, Niu S, Zhang G, Stoll B, Finegold MJ, Holst JJ, Hadsell D, et al. (2006) GLP-2 receptor localizes to enteric neurons and endocrine cells expressing vasoactive peptides and mediates increased blood flow. Gastroenterology 130:150-164.

Isenberg JI, Wallin B, Johansson C, Smedfors B, Mutt V, Tatemoto K, and Emas S (1984) Secretin, VIP, and PHI stimulate rat proximal duodenal surface epithelial bicarbonate secretion in vivo. Regul Pept 8:315-320.

Jang HJ, Kokrashvili Z, Theodorakis MJ, Carlson OD, Kim BJ, Zhou J, Kim HH, Xu X, Chan SL, Juhaszova M, et al. (2007) Gut-expressed gustducin and taste receptors regulate secretion of glucagon-like peptide-1. Proc Natl Acad Sci US A 104: 15069-15074.

Jeppesen PB, Gilroy R, Pertkiewicz M, Allard JP, Messing B, and O'Keefe SJ (2011) Randomised placebo-controlled trial of teduglutide in reducing parenteral nutrition and/or intravenous fluid requirements in patients with short bowel syndrome. Gut 60:902-914.

Konturek SJ, Bilski J, Tasler J, and Laskiewicz J (1985) Gut hormones in stimulation of gastroduodenal alkaline secretion in conscious dogs. Am J Physiol Gastrointest Liver Physiol 248:G687-G691.

Little TJ, Gupta N, Case RM, Thompson DG, and McLaughlin JT (2009) Sweetness and bitterness taste of meals per se does not mediate gastric emptying in humans. Am J Physiol Regul Integr Comp Physiol 297:R632-R639. 
Liu X, Murali SG, Holst JJ, and Ney DM (2008) Enteral nutrients potentiate the intestinotrophic action of glucagon-like peptide- 2 in association with increased insulin-like growth factor-I responses in rats. Am J Physiol Regul Integr Comp Physiol 295:R1794-R1802.

Ma J, Bellon M, Wishart JM, Young R, Blackshaw LA, Jones KL, Horowitz M, and Rayner CK (2009) Effect of the artificial sweetener, sucralose, on gastric emptying and incretin hormone release in healthy subjects. Am J Physiol Gastrointest Liver Physiol 296:G735-G739.

Mace OJ, Affleck J, Patel N, and Kellett GL (2007) Sweet taste receptors in rat small intestine stimulate glucose absorption through apical GLUT2. J Physiol 582:379392.

Margolskee RF, Dyer J, Kokrashvili Z, Salmon KS, Ilegems E, Daly K, Maillet EL, Ninomiya Y, Mosinger B, and Shirazi-Beechey SP (2007) T1R3 and gustducin in gut sense sugars to regulate expression of $\mathrm{Na}^{+}$-glucose cotransporter 1. Proc Natl Acad Sci U S A 104:15075-15080.

Mizumori M, Ham M, Guth PH, Engel E, Kaunitz JD, and Akiba Y (2009) Intestinal alkaline phosphatase regulates protective surface microclimate $\mathrm{pH}$ in rat duodenum. J Physiol 587:3651-3663.

Mizumori M, Meyerowitz J, Takeuchi T, Lim S, Lee P, Supuran CT, Guth PH, Engel E, Kaunitz JD, and Akiba Y (2006) Epithelial carbonic anhydrases facilitate $\mathrm{PCO}_{2}$ and $\mathrm{pH}$ regulation in rat duodenal mucosa. J Physiol 573:827-842.

Mourad FH, Barada KA, Abdel-Malak N, Bou Rached NA, Khoury CI, Saade NE, and Nassar CF (2003) Interplay between nitric oxide and vasoactive intestinal polypeptide in inducing fluid secretion in rat jejunum. $J$ Physiol 550:863-871.

O'Dorisio TM, Cataland S, Stevenson M, and Mazzaferri EL (1976) Gastric inhibitory polypeptide (GIP). Intestinal distribution and stimulation by amino acids and medium-chain triglycerides. Am J Dig Dis 21:761-765.

Orskov C, Holst JJ, Knuhtsen S, Baldissera FG, Poulsen SS, and Nielsen OV (1986) Glucagon-like peptides GLP-1 and GLP-2, predicted products of the glucagon gene, are secreted separately from pig small intestine but not pancreas. Endocrinology 119:1467-1475.
Reimann F, Habib AM, Tolhurst G, Parker HE, Rogers GJ, and Gribble FM (2008) Glucose sensing in L cells: a primary cell study. Cell Metab 8:532-539.

Reimann F, Williams L, da Silva Xavier G, Rutter GA, and Gribble FM (2004) Glutamine potently stimulates glucagon-like peptide-1 secretion from GLUTag cells. Diabetologia 47:1592-1601.

Takeuchi K, Kita K, Hayashi S, and Aihara E (2011) Regulatory mechanism of duodenal bicarbonate secretion: roles of endogenous prostaglandins and nitric oxide. Pharmacol Ther 130:59-70.

Takeuchi K, Yagi K, Sugamoto S, Furukawa O, and Kawauchi S (1998) Involvement of PACAP in acid-induced $\mathrm{HCO}_{3}{ }^{-}$response in rat duodenums. Pharmacol Res 38:475-480.

Theodorakis MJ, Carlson O, Michopoulos S, Doyle ME, Juhaszova M, Petraki K, and Egan JM (2006) Human duodenal enteroendocrine cells: source of both incretin peptides, GLP-1 and GIP. Am J Physiol Endocrinol Metab 290:E550-E559.

Thulesen J, Knudsen LB, Hartmann B, Hastrup S, Kissow H, Jeppesen PB, Ørskov C, Holst JJ, and Poulsen SS (2002) The truncated metabolite GLP-2 (3-33) interacts with the GLP-2 receptor as a partial agonist. Regul Pept 103:9-15.

Tsai CH, Hill M, Asa SL, Brubaker PL, and Drucker DJ (1997) Intestinal growthpromoting properties of glucagon-like peptide-2 in mice. Am J Physiol Endocrinol Metab 273:E77-E84.

Yao B, Hogan DL, Bukhave K, Koss MA, and Isenberg JI (1993) Bicarbonate transport by rabbit duodenum in vitro: effect of vasoactive intestinal peptide, prostaglandin $\mathrm{E}_{2}$, and cyclic adenosine monophosphate. Gastroenterology 104: 732-740.

Zhang F, Klebansky B, Fine RM, Xu H, Pronin A, Liu H, Tachdjian C, and Li X (2008) Molecular mechanism for the umami taste synergism. Proc Natl Acad Sci US A 105:20930-20934.

Address correspondence to: Dr. Yasutada Akiba, West Los Angeles VA Medical Center, 11301 Wilshire Blvd., Bldg. 114, Suite 217, Los Angeles, CA 90073. E-mail: yakiba@mednet.ucla.edu 